\title{
A review of historical management arguments for Northern Goshawk Accipiter gentilis proposed by Norwegian hunters, scientists and conservationists
}

\author{
Vegard Gundersen ${ }^{1,2} \&$ Morten Kraabø1 $1^{1,3}$ \\ ${ }^{1}$ Norwegian Institute for Nature Research, NO-2624 Lillehammer, Norway; ${ }^{2}$ e-mail: vegard.gundersen@nina.no ; ${ }^{3}$ e-mail: \\ morten.kraabol@nina.no
}

\begin{abstract}
The Northern Goshawk Accipiter gentilis has influenced the lives of people in rural areas since the beginning of Norwegian civilization. In the first known written sources about the species, during the Viking age, the goshawk symbolized heroism and bravery. Goshawks were historically connected to mysticism and superstition, as evidenced first in old runes and later in fairy tales and common adages. This paper reviews the scientific and ethical argumentation for the management strategy in that took place between 1845 and 1971, when the goshawk was considered a bounty species. At the start of this extermination period, a small number of influential scientists convinced the government to establish a bounty on goshawks that is dictated in hunting legislation from 1845, 1863 and 1899 . From 1910 onward, the debate concerning the bounty policy became more diverse, broadening the discussion to include moralistic and conservational issues and finally leading to the protection of goshawks in 1971. Hunting legislation beginning the 1970s refined the utilitarian view of nature by including functional aspects of game species removing the distinction between "vermin" and "utility" animals in 1981. The goshawk has been listed on Norway's Red List of Threatened Species since 1984. This review illuminates how scientific, aesthetical and ethical arguments were all interwoven in the policy and management for the Northern Goshawk over a relatively short historic timeframe.
\end{abstract}

Keywords: Bounty, red list, hunting, extermination, conservation, game management

\section{INTRODUCTION}

The status of Norwegian populations of the threatened Northern Goshawk Accipiter gentilis (hereafter goshawk) has received particular attention in recent years (Grønlien et al. 1993, Grønlien 2004, Knoff 1996, 1999a, b, Sandvik 1996, Selås, V. 1998, Hafstad 2002, Hafstad et al. 2003, Gundersen et al. 2004). Some biologists expressed concern about the goshawks' future as early as the early 1900s due to state-sanctioned extermination policies (Broch 1912). Historically, many biologists, hunters, and farmers had argued that goshawks were too abundant - competing with hunters and preying on substantial numbers of poultry on farms (Selås, I. 1998). The goshawk controversy reached a climax in Norway around 1971, when protection for raptors (including the goshawk) was enacted. This was difficult to understand for those who maintained that goshawks were an important factor regulating small-game species. The situation was exacerbated because scientists had observed a long-term decreasing population trend in forest small game species during the period before the protection of raptors (Hesthagen 1975, Wegge \& Grasaas 1977, Wegge 1979, Marcström 1979, Hjeljord 1980, Lindén \& Rajala 1981, Henttonen 1989, Smedshaug 2001).

Throughout the 1970s, various studies indicated a decreasing population trend of the goshawks (for review see Gundersen et al. 2004). For obvious reasons this decreasing trend was seen as a response to the dramatic changes in forest landscapes from the shift in harvest regimes from selective cutting to clear-cutting in the 1940s-50s (Lind 1970, Norderhaug 1978, Sollien 1979). This decreasing population trend was seen throughout a large proportion of goshawk territories in North America (Shuster 1980, Hayward \& Escano 1989, Reynolds et al. 1992, Crocker-Bedford 1990, 1995, 1998, Niemi \& Hanowski 1997a, b), Central Europe (Norderhaug 1978, Bijlsma 1991) and Fennoscandia (Nilsson 1981, Forsman \& Ehrnstén 1985, Widén 1989, 1997, Tømmerås 1993, Selås, V. 1998). The goshawk has been on Norway's Red list of threatened species since 1984 (Kålås et al. 2010).

The goshawk is among the best-studied forest raptors in the Nordic countries and in North America (Reynolds et al. 1992, Kennedy 1997, Gundersen et 
al. 2004). Conservation and protection of goshawks in forest management continue to cause conflict in Norway (e.g. Haugan \& Søgnen 1999, Knoff 1999a, Hafstad 2002). Using the goshawk in Norway as an example of a thoroughly researched species, this paper aims to review and dig deeper into the arguments for management and conservation of a focal species in research and politics. To relate specifically to the goshawk controversy, the paper focuses on three central and diverse groups of people: hunters, scientists and conservationists.

\section{MATERIAL AND METHODS}

A comprehensive literature search was undertaken to identify as much of published literature relevant of Northern goshawk in Norway as possible. We used the review by Inge Selås (1998) as a starting point to identify relevant sources. We present unpublished reports and Internet sources in instances when no other sources are available. All sentences presented in quotation marks are originally written in Norwegian language, and were translated by the authors.

\section{RESULTS}

\subsection{Goshawks in the literature before 1845}

In Norway, remnants from goshawks have been found in archaeological excavations from the Stone Age (Schaaning 1927). However, relatively little is written specifically about raptors, or birds in general, in Norse mythology. This was a period when Norse Gods were thought to own the world, and everything was written in that context. Thor was the son of Odin, the most powerful of all the Norse Gods, and he had a wife Siv. She owned a magic hawk skin, in such a way that she could at any time become a raptor (Heimskringla). Norse mythology mentioned the hawk Verfolne in the ash Yggdrasil, and as the chief's hunting raptor (Volsungesagaen). From Norwegian runes (runic inscriptions on wood), we can mention a rune from June 1197 A.D. on the stave church of Vinje (no longer standing): “...(It) is not about witches' black magic, sea-warrior hawks have fallen down, and they continually generate controversy" (Olsen 1941). Hawks are connected in this passage to heroism and bravery.

People lived in a strong relationship with nature during these times, with seasonal changes and a long dark wintertime influenced their culture and mentality. Goshawks have influenced people's daily life for a long period of time, especially on the mountain pastures and farms deep in the forests. The goshawk has been used to predict the weather (Waage \& Jonassen 2004), and more than 200 different old farm names in Norway include the word "hauk" (hawk) (Rygh 1898). The goshawk is also the origin of the male name "Hauk".

There is a common superstition that looking at birds' behaviour gives omens about people's daily life, for example weather, death, birth, suicide and crop production (Waage \& Jonassen 2004). The myths tell us about a greedy and hated bird, but also a mystical bird. It is said about the goshawk "that he lost his claws in the springtime, because he shouldn't be able to kill the parents of young birds"... "It is God that manages things in such a way". Otherwise, "you should be able to protect the poultry against goshawk if you weighed them in a hamper on Easter Eve. Then the goshawk wouldn't have enough power to kill them in the summer" (Waage \& Jonassen 2004). People had a deep respect for the raptors, especially the goshawks in the forests. They had prejudices against mentioning the raptors by name because this was dangerous and would bring death and adversity. To protect against adversity, the farmers' usual advice was to hang up dead goshawks over the barn door to avoid evil spirits. There was also a widely spread superstition that when you got feathers from goshawks (and also other raptors) in your bed, a sick person would be in pain and close to death for a long period without his life ending (Storaker 1928, Waage \& Jonassen 2004).

Many of these local traditions were written down in the 19th century and are mentioned often in traditional Norwegian fairy tales (Asbjørnsen \& Moe 1845). The name goshawk is used in a figurative sense. Examples of this could be; "Then Hans formed a dove (pigeon), and Bonde Varskjegg formed a big goshawk, and set after the dove" (Bonde Værskjegg), "After a while the king went down to his farm again; then came a big goshawk after his poultry, and all the people started to clap their hands and to yell. There it is! There it is! The king took the gun and started aiming, but he couldn't see as far as that." (Tro og Utro), "..., because he one day tried to open the coffin, and the sorceress put out her dry claw, like a hawk's claw, and slammed down the cover close to his nose." (Lundeætten). The word hawk is also used as a verb, meaning screaming like a hawk. (Presten og klokkeren, Tobakksgutten). In a letter from 1874, goshawks was used as a synonym "The teacher drifted to and from our house and swooped down like a goshawk here, and pressed us" (Hovden 1874), and "... and a bailiff like a goshawk!" (Hjemmusa og fjellmusa) (above: fairy tales from Asbjørnsen \& Moe 1845).

There are some old adages dealing with the goshawk, in the meaning of a power-hungry person. Here are some examples of adages that are still in use in daily life in Norway: "It isn't all the birds that are hawks, some of them are only cuckoos", "It is hawk over cock ", "When the hawk is gone, the hare is proud", "When the hawk comes, the cocks forget the pecking order", "You shouldn't put the hawk in the hen house", "Hawk over hawk, as long as there are two of them left", "It is 
every hawk he is good for" (Waage \& Jonassen 2004). Both the fairy tales and the adages are examples of attitudes towards and opinions on goshawks in daily life in old times in Norway.

\subsection{Putting a bounty on goshawks (1845-1868)}

In the history of Norwegian legislation, the occurrences of laws about hunting are known from some parts of the country before the Viking Age (Landskapslovene before 800 A.D.). The first national law, Magnus Lagabøters law from 1276, gave legal provision concerning the hunting mainly of big game species. Christian III's law of 1604 and Christian V's law of 1687 repeated this legal provision about big game hunting. However, from 1350-1600, the population of Norway was at a low level due to the Black Death, so there was no reason to regulate hunting. The reason for the similarity in legislation during the Viking Age and the Middle Ages is explained by very similar hunting methods. The first changes came when firearms became common among hunters. This enabled all people to hunt all kind of bird species until the first act was founded in 1845, and descriptions of methods for hunting goshawks throughout this period are common (Anonymous 1845a). In an article from a forested Norwegian county, you can find the following short description of goshawks: "The goshawks, Falcon arugnofus, visit often traps of prey, and there you can kill them. When the goshawks nest, they are easy to kill, because they will defend the young." (Wille 1786, Anonymous 2004). In 1838, Halvor Heyerdahl Rasch, a prominent Norwegian professor in zoology, termed the goshawk problem in this way: The goshawks ruin the farms' poultry in the autumn and spring. In the summer the goshawks spend time deep in the forests causing huge damage to small game species like forest grouse [Tetraonidae] and mountain hare [Lepus timidus]. There should be put a bounty on goshawks (Rasch 1838). He also published the book 'Hunting in Norway', and thereby provided the final justification for the foundation of the Act for the Elimination of Predators and Protection of Other Game Species in 1845 (Anonymous 1845b). Among other things included in the law, the bounty included not only the largest predators (such as wolf Canis lupus, brown bear Ursus arctos, wolverine Gulo gulo, and lynx Felis lynx), but also species like Eagle Owl Bubo bubo, Golden Eagle Aquila chrysaetos and goshawk.

These principles of elimination of so-called vermin species influenced the Norwegian hunting legislation for a very long period. In hunting laws from 1863 and 1899 , the number of species subject to bounties increased without record of any public protests. The goshawks became a symbolic species that was viewed as the main threat to poultry and small-game species. Rasch (1860) claimed that the goshawks caused "more damage alone than all the other raptors together", and that hunting legislation should "with a large bounty level encourage the elimination of this species" (Rasch 1860). In 1845 the bounty level for Eagle Owl and goshawk constituted approximately one tenth of the bounty for wolf. Rasch argued that this was too low relative to the large damage that goshawks caused (Rasch 1860). In 1863 the bounty level was more than doubled. In a lecture presenting the bounty statistics for 1861-65, Rasch was not satisfied with the species identification skills of the servants (Rasch 1862, 1868). He mentions what he called the "...meaningless high number of 4254 for goshawks killed in 1865" (Figure 1). Based on his estimation of Norway's goshawk population size, Rasch proposed that bounty hunting should remove 800 individuals per year. Rasch was afraid that the bounty on goshawks would encourage inadvertent removal of other raptors species, and lead to population declines of more useful mouse-eating raptor species. Rasch may have disputed the accuracy of the number of the goshawks killed in 1865. However, Rasch could not have known at that time that the annual number of goshawks killed would be approximately the same for the next 67 years (Figure 1).

\subsection{The period of intensified persecution of goshawks (1868-1932)}

\subsubsection{Bounty statistics in the period $1868-1932$}

In the new hunting act of 1863, the Act for the Elimination of Predators and Protection of Other Game Species, the number of bounty species increased, as well as the reward for goshawk being doubled (Anonymous 1863a). The premium increased again in 1899 (Anonymous 1899), but thereafter there were no changes in the bounty value for 30 years (Anonymous 1932). By neglecting the consumer price index the relative value of each killed goshawk decreased dramatically in the period 1899-1929 (Figure 1).

A Norwegian program for extermination of (small game) predators (NPEP) ran during 1900-1914, intensifying the persecution of goshawks. Yet this program did not substantially increase in the number of goshawks killed per year. In the 30-year period of 1885-1915 (when bounties were allotted for an average of 4500 goshawks per year), over 5000 birds were killed in some years. If forests containing goshawks in Norway cover approximately $100000 \mathrm{~km}^{2}(30 \%$ of the country's land area), 4 to 5 goshawks were killed per $100 \mathrm{~km}^{2}$ each year. By comparison, present goshawk pair density estimates are approximately 3 occupied territories per $100 \mathrm{~km}^{2}$ (plus an unknown proportion of young without territories), with an annual production of about 1.5 fledglings per territory (Gundersen et al. 2004). Accordingly, if we assume that the number of 


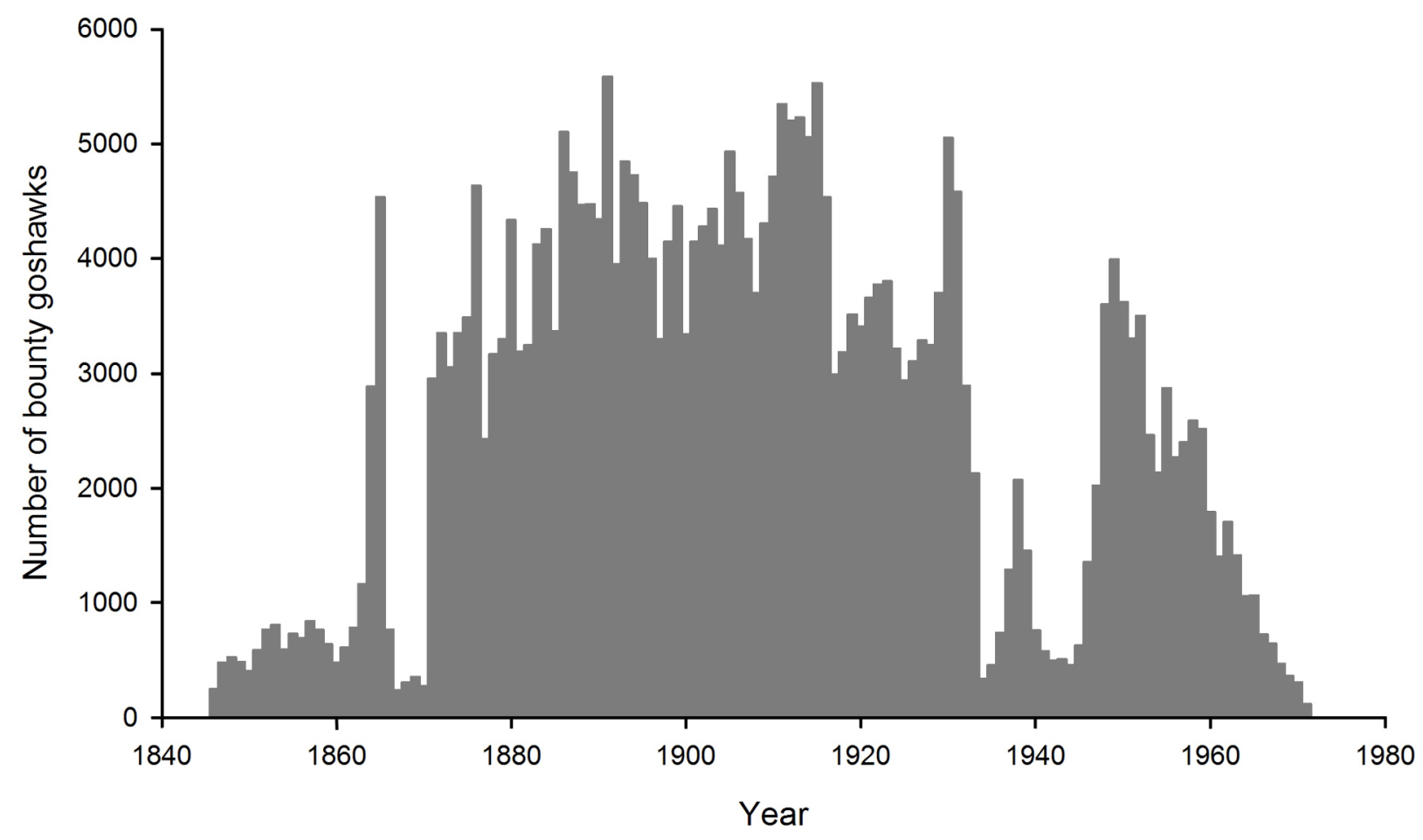

Figure 1. Bounty statistics for goshawks killed in the period 1845 to 1971 (Statistisk Sentralbyrå 1978). Several factors can influence the numbers of goshawk recorded killed in a particular year (for a comprehensive discussion on trends and reasons for these trends, see Gundersen et al. 2004).

killed goshawks is accurate, the species had to be more abundant and with greater production at the beginning of the 1900s than they are today. Yet as Rasch himself noted, the number of killed goshawks is almost certainly overestimated because of inaccurate species identification.

\subsubsection{The debate among key scientists}

Some of the justification given for the extermination of goshawks and other predators was: “...that Norway's domestic animals get free from their dangerous enemy, and these ravages caused higher loss for the national economy than should be expected." (Rasch 1845). Scientists, hunters and farmers who clearly had a strong dislike of the species dominated the early written history of goshawks. However, some authors questioned the morality of promoting extinction. An anonymous writer asked "...who is willing to take the complete responsibility for having caused a species to become extinct?" and stated: "...where nature can be left undisturbed, you can find that harmony has stepped forward - at last" (Anonymous 1910). In 1912 a famous Norwegian essayist wrote: "It will be sad to never see a flying goshawk in the air or a snake wriggle along in the heather. All these harmless species have a tremendous and pleasant spirit. We can with a quiet conscience leave some left of animals with claw and fang"
(Kjær 1912). Nonetheless, opinions regarding raptors among scientists changed slowly. Leading zoologists around the 1900s were more concerned about rare and threatened species, and spots of occurrence, than issues of species protection as a whole. Human exploitation was not questioned at this time, and conservation issues were not yet identified. A distinction between so-called vermin and the more desirable utility species in hunting legislation was generally not questioned prior to 1910 .

Scientific justification for Norway's raptor management was also characterized by ambiguousness in the personal opinions of the influential experts. One of the leading zoologists who succeeded Rasch around the turn of the century, Robert Collett, admitted that "we have no scientific evidence that a strong decline in the population of raptors directly results in a corresponding increase and stabilization in the population of small game species" (Broch 1954). Collett's successor, Hjalmar Broch, viewed Collett's positions on goshawks as evasive, because Collett gave his consent to the definition of bounty on 17 species in 1898, when he was consulted as an expert in the committee of the hunting act of 1898 (Anonymous 1898, Collett 1898). Collett wrote about goshawks: "In addition to being one of the most common raptors in the country it is also the most harmful of them all. In spite of their greed they are in fact cowardly birds, which escape as soon as they meet opposition, and take to wings because of only a couple of angry crows" (Collett 
1921). Collett published in 1905 'Norwegian bounty birds', which was an instruction book for the tenant servant on behalf of the Ministry of Agriculture. In this book he described visual characteristics, morphology and behaviour for both bounty birds and other birds, and evaluated the risk of mistake. In case of confusion he gave detailed drawings of head, feather and claw. Even if this presentation was descriptive and quite neutral in form, he wrote that the goshawk was "our most harmful raptor" (Collett 1905). In 1845, Professor Rasch argued against putting a bounty on goshawks because of the risk of confusion with Common Buzzard Buteo buteo and Sparrowhawk Accipiter nisus (Rasch 1845). The Ministry of Agriculture expected that this book of instructions would lead to fewer mistakes of identification.

Both Rasch and Collett were proponents of a utilitarian view of nature and their views on hunting were considered to be scientific. Rasch was viewed as one of the pioneers in applied science because of his belief that science should serve society, trade and industry (Gran 1911). By carrying on this utilitarian tradition, Collett became popular in hunting associations. This made it easier for him to elicit aid from these groups concerning other controversial questions, such as conserving the beaver Castor fiber, a species that was threatened at that time.

Criticism of the utilitarian view on nature was initiated by Broch and became much stronger in the 1920s. In 1920 Broch complained of the "The game management's one-sided protection of the game species and embittered fight against raptors", which contributed to "change the natural balance in nature, and deprive nature of local characteristics" (Broch 1920). Ten years later he articulated the importance of predator species: "predators have extraordinary large meaning in nature's household". Broch's view was supported by August Brinkmann's studies of diseases among populations of Willow Grouse Lagopus lagopus (Brinkmann 1926). At that time, Brinkmann emphasized that diseases were the main factor explaining the fluctuations of Willow Grouse populations, and not the pressure from predators. He maintained that the predators were "healthy components in nature ", killing weak and ill individuals and thereby preventing infectious diseases from spreading in the population. A game management program that promoted an indiscriminate elimination of predators was, in his opinion, completely contrary to a healthy forest ecosystem (Brinkmann 1926). In the period after 1920, Broch, Brinkmann, and later Sigmund Huse and Edvard K. Barth, promoted their view that natural processes were best, and stated that all "Human intervention in nature always ended badly" (Broch 1920). Several passages in their scientific papers spoke of the "balance in nature", and that all human intervention disturbs this balance (e.g. Broch 1920, Barth 1957, Huse 1958). Their papers contain many aesthetic passages originating from experiences with goshawks in forests, and describe a forest landscape that depends on the presence of raptors (e.g. Huse 1958). These new trends contradict Rasch's and Collett's utilitarian view of nature, and thus represent an early stage of modern conservationism.

Support for goshawk bounties still dominated management policy during the years between the two world wars, although some continued to raise objections to the raptor control programmes. The Norwegian Hunting Association (NHA) came particularly under scrutiny from a handful of zoologists. There are many examples of violent disagreements between the two groups. As an example, Broch criticized The Vicepresident of NHA: "The Vice-president showed (by statistics) that the war against goshawks has been without any effect, because the total bounty payment has been practically stable, or - to speak in plain Norwegian - the money has been thrown out of the window" (Broch 1928a). This debate was influenced by pressure from international scientific societies. In a report from an international bird conference, Professor Broch wrote: "The conference focused also on the drastically declining trends of all raptors in Norway and Denmark. This issue should be of interest to us due to statements at the London conference giving a clear expression of the common opinion among leading European ornithologists that "there is something rotten " in the Norwegians' treatment of their birds" (Broch 1928b). New data from the zoologists had generated a discussion about the raptors' role in nature. However, the Norwegian hunting legislation did not change until many years later. The bounty on goshawks still existed in 1929, even though the value of the bounty had not increased for 30 years.

\subsubsection{The early role of the Norwegian Hunting Association}

In addition to select natural scientists' endorsements of bounty programs, the persecution of goshawks around the 1900s was strongly promoted by the Norwegian Hunting Association (NHA), on both national and local levels. The NHA used their published literature to motivate their members to eradicate goshawks (Table 1), although the NHA as a body may have followed a more moderate line than these comments indicate (e.g. Eger 1924). The goal of total elimination of goshawks became a strong desire for many hunters. The precarious position of the goshawk can be illustrated by the fact that NHA paid a significant extra premium (in addition to the premium from State and County) for each goshawk killed during winters between 1876 and 1907 (e.g. Anonymous 1903). At the same time the NHA spread information about comprehensive damage goshawks inflicted on national game resources. The 
Table 1. Selected quotations from the Norwegian Hunting Association's periodical (Norsk Jæger- og Fiskerforenings Tidsskrift) during the period of 1868-1932 when goshawk extermination was pursued.

"Fit with a hearty boldness, slyness and persistency, they try to dupe the prey." (Anonymous
1894: p. 86)
"These two hawks (goshawk and sparrowhawk) are among our worst robbers and the most
harmful raptors for game bird species." (Anonymous 1906: p. 102)
"In this particular area the hunting of predators and raptors has been so effective that there
exist only a few of them. The results of this hunting are that populations of forest grouse
species have increased enormously. You can now see flights of capercaillie in the hundreds and
in the birch forests black grouse take to the wing all the time." (Anonymous 1910: p. 119)
"Some of the old goshawks spend the winter in woodlands, and what they can do during the
wintertime is incredible. When they have found an area with forest grouse, they pick up a
steak every day. Hunting (bulvantrap) would easily stop this ravaging of the wood grouse."
(Jenssen 1931, p. 173)
"In the woodland is the goshawk, a greedy raptor ruining the birds. This raptor does the same
whether the bird is ill or healthy; this is what I have discovered." (Gjorde 1932: p. 181)

NHA played a key role in educating and informing hunters about effective hunting methods, and engaged and employed experts on hunting raptors and predators (Anonymous 1906). These experts travelled around the country giving local seminars, demonstrating traps and sharing personal experiences, promoting successful hunting of goshawks (e.g. Feragen 1903, Helland 1914, Johnsen 1929). In addition, the NHA also composed and distributed a brochure about hunting of predators, raptors and crows, and lent traps to hunters.

In 1909 the Association for the Elimination of Predators was founded, involving central members of NHA. The background of this association was their desire for a more offensive control programme against predators and raptors. This association endured only three years, but nevertheless had a significant impact on the war against predators and raptors in subsequent years. They used harsh words to promote their nonbalanced utilitarian views in their propaganda materials.

We have earlier mentioned that Professor Broch was the first scientist who openly criticized the popular policy of extinction of raptors. Already in 1912 he criticized the uncritical killing of raptors to the Secretary of the NHA, and included a talk at the half-year meeting of the NHA. He asked for more deliberation in the evaluation of raptors: "Nature doesn't only show us pure vermin and pure utility animals" (Broch 1912). In the discussion after the talk, the President of the NHA concluded on behalf of the NHA that "We don't wish to eliminate any species in our fauna" (Broch 1912). This was a newly stated policy for the NHA. Even if the basis of argumentation from the NHA was mainly linked to economics, there were also ethical and philosophic considerations that legitimated the elimination of the goshawks. The Society for the Prevention of Cruelty to Animals was engaged in vilifying the apparent 'torture' that the raptors cause other species. The raptor's 'cruel' treatment of fellow creatures justified humanity's cruelty for the sufferings caused by hunting and the use of poisons. Every killed raptor resulted in hundreds of other innocent animals and birds being saved from the torture of being caught and eaten, and this could be an argument to kill goshawks in a bestial way: "...to shoot the old goshawks when the young birds are in the nest" (Anonymous 1894). The Hooded Crow Corvus cornix was the only species less valued than the goshawk, and there was concern that the extermination of goshawks increased the Hooded Crow population (Anonymous 1925).

The NHA took notice of scientific pressure in the 1920s and 1930s, but the main policy of extermination continued. After Rasch and Collett, no other scientists supported the extermination of goshawks and the NHA had lost its good relationship with the zoologists. The situation became even worse as the successors of Rasch and Collett, namely Broch and Brinkmann, criticized the NHA publicly, and this led the Professor and Vice-president in the NHA to admit: "A purposeless 
elimination of these raptors is objectionable from a hunting point of view" (Dahl 1927). However, the NHA has never issued an official statement that the war against raptors was wrong. The case of raptors put the NHA in an uncomfortable position: at the same time that they lost their scientific anchor, they also lost their raison d'être as well as the war against predators.

\subsection{Towards the protection of goshawks (1932-1971)}

After the cessation of bounty from the State (in 1924) and the County (in 1926), there were only a few municipalities that still paid a significant bounty premium for killed goshawks. As a consequence, the average hunter had no longer any reason to report killed goshawks in the 1930s, providing no dependable public record of the number of goshawks killed during this decade. World War II further disrupted the collecting of bounty statistics. In 1949, the number of goshawks killed soared again to over 4000 individuals. The premium from NHA was again high, and hundreds were encouraged to report killed goshawks again. From this year and towards the protection year of 1971, an almost linear decline in the number of goshawks was reported killed (Figure 1).

Herman L. Løvenskiold, the successor of both Broch and Brinkmann, had from his early years a more subtle explanation of the raptors' role in cyclic populations (Løvenskiold 1925), and he wrote in 1947: "The goshawks have been the worst sufferers, but without doubt could be a threat to game species. Anyway, the goshawks have a natural function in nature and were much more common earlier with more game species" (Løvenskiold 1947). However, the distinction between vermin and utility species continued. In a bird handbook from 1946, the following description of goshawks is sited: "The species is among our most destructive raptors. As an example I can mention how it ravages the poultry in a farm, taking 10 fowls on one farm and more than 30 in the neighbour farms" (Økland 1946). The 1950s and early 1960 s can be recognized as a renaissance period with very high hunting pressure on raptors. The NHA gave yearly prizes to active hunters and at local level the elimination of raptors could be very intensive.

In 1952, the book 'Raptors and game management' (Hagen 1952), inaugurated a new era of knowledge about the raptors' role in the ecosystem. Hagen's focus in this book was that the number of prey determined the number of raptors, and not the opposite. This controversial hypothesis generated both a large scientific discussion and much new research on the raptors. Hagen himself did not take a definite stand on whether or not to hunt raptors, but he argued that elimination of raptors had only short-term and local effects. In addition, he questioned the belief in the goshawk being a single-species predator: "Someone declared that also red fox, goshawk and Eagle Owl are specialized to eat small-game species. The goshawks could be that in some cases, but more commonly the goshawks eat a large number of individuals, both birds and animals - more than 121 different native species have been found in their diet. Most common are red squirrels [Sciurus vulgaris], Jays [Garrulus glandarius] and thrushes [Turdidae]. Mountain hare and forest grouse are included in approximately $33 \%$ of the goshawks' diet" (Hagen 1964). Additional studies indicated that goshawks have a very diverse diet, and that thrushes and jays were important prey (MuntheKaas Lund 1950, Hagen 1952).

In the 1950s criticism of the hunting legislation increased (new Hunting Act in 1951, Anonymous 1951), including criticism of the attitudes of earlier scientists (Barth 1957, Huse 1958). Huse (1958) asked the relevant question "Shall they have the right to live?", and his answer was clear both by scientific reasons as well as aesthetical arguments: "Raptors flying high up in the sky are symbolic of the freedom and spirit of Norwegian nature" (Huse 1958). Barth (1957) became upset when he discovered that Rasch's "bloody hunting stories" were a syllabus for all Norwegian children at primary school, for many years after 1863 (Anonymous 1863b).

In the 1960s and 1970s, the arguments for bounty on goshawks became weaker and less common (but see Anonymous 1969, Anonymous 1972). In addition, there were many voices being raised to protect the goshawk. Willgohs (1968) wrote "in the last few years you can find a noticeable change in the opinion towards raptors of the man in the street". There was a general demand that this shifting opinion should be reflected in the law (Barth 1982), and in the 1960s there was also concern about declining trends for goshawks and other raptor species, due to habitat destruction, harmful chemicals (DDT) and other pollutants (Newton 1979). As a consequence, all raptors and owls became protected by law in 1971, although another ten years went by until the hunting act of 1981 ended the distinction between vermin and utility animals (Anonymous 1981). This ended the official bounty statistics for goshawks, although opinion among hunters was rather stubborn. The debate is still present at all levels.

\subsection{Goshawk in a new era (1971-present)}

\subsubsection{As a focal species in research}

The research interest in goshawks has increased over the last 30 years (Figure 2), as it has for many other bird species. Scientific studies have also evolved over this period, going from simplistic correlations towards a progressively functional focus. In the period before the 1970s, there were some scattered traditional ecological 


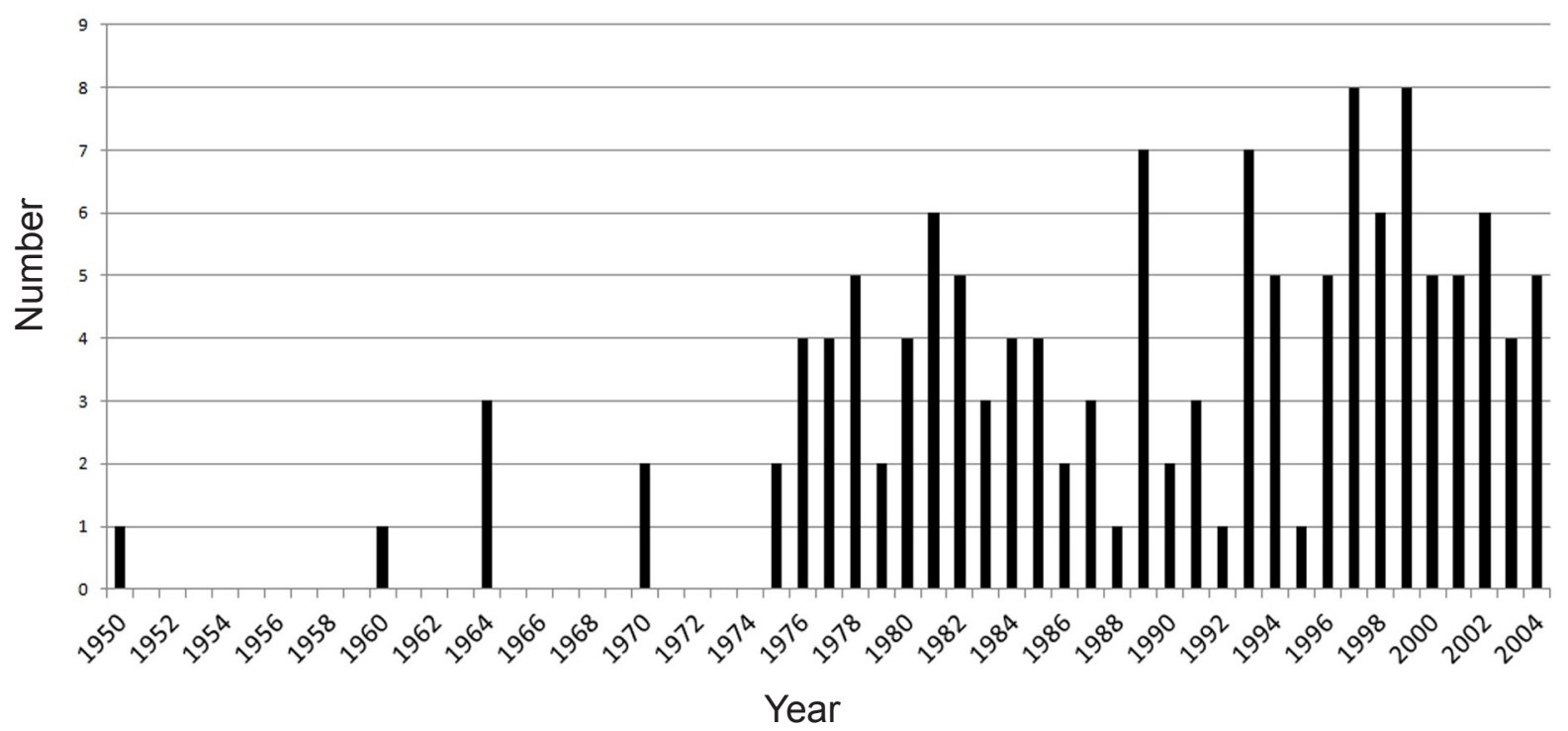

Figure 2. Articles published in the scientific literature addressing the ecology and demography of goshawks from Norway, Sweden and Finland (adapted from Gundersen et al. 2004).

studies, dealing with feeding, breeding and environmental adaptations (Gundersen et al. 2004). In the 1970s most studies dealt with effects of goshawk predation on the population level of small-game species. Several studies tried to correlate parameters for goshawk demography and density with small-game species demography and density (numeric and functional responses).

As a secondary result of these studies, researchers observed decreasing goshawk population trends believed to be due to clear-cutting practices in boreal forests (Gundersen et al. 2004). At the same time, some experimental studies indicated that generalist predators had a more significant role in regulating small-game species than earlier expected (Marcström et al. 1988). This was later supported by an observed substantial increase in the population level of small-game species, after a dramatic decline of the key generalist predator, red fox, due to outbreak of the disease sarcoptic mange (Lindström et al. 1994, Selås et al. 1995).

These new findings set the focus on the goshawks again, and highlighted the need for more experimental studies concerning goshawks and their environment. Additional ecological and demographic studies were conducted in the 1980s and 1990s. Many popular scientific articles were published in the 1990s, arguing that decreasing goshawk population trends were linked to forest logging activity (e.g. Hals 1998, 1999a, b, Haugan \& Søgnen 1999, Pedersen 2000).

\subsubsection{The goshawk as a threatened species}

The goshawk is listed in category II in the Convention on the Conservation of European Wildlife and Natu- ral Habitats, also known as the Bern Convention. This convention was adopted on September 1979 in Bern (Switzerland) and was ratified on 1 June 1982. At present, 45 contracting parties including 39 member States of the Council of Europe, as well as the European Community, Monaco and four African States are party to this agreement. In the preamble to the Bern Convention it is stated that: "... wild flora and fauna constitute a natural heritage of aesthetic, scientific, cultural, recreational, economic and intrinsic value that needs to be preserved and handed on to future generations...". The Bern convention has been an important and controversial tool for the political protection of the goshawk and habitat, because of limited ecological knowledge about the species at the same time as the political power driving conservation has increased (Skåret 1997).

The goshawk was listed as a "Vulnerable" species in 1984 (Anonymous 1984). In the period 1988-1996 the goshawks' status was revised to "Uncertain" on the national red list, because of limited information about population level and threats (Anonymous 1988, 1992). In 1996 it was listed as "Rare", until 1999 when the goshawk again became listed as "Vulnerable" (Anonymous 1999). Today, the goshawk status on the red list is degraded one category down from Vulnerable to "Near Threatened" (Kålås et al. 2010). Norway has used IUCN, International Union for Conservation of Nature, categories and criteria since 2006.

Despite being one of the most intensively studied bird species in the boreal forests, it is difficult to distinguish between causes and effects regarding the question of population trends and threats (Gundersen et al. 2004). This is the constant dilemma in the red list approach and methodology (Gundersen \& Rolstad 
Table 2. Excerpts from a 2003 interview of the Chief of Information of the Norwegian Hunting Association (NHA) by a reporter from the World Wildlife Foundation (WWF), including comments from the General Secretary of the Norwegian Ornithological Society (GSNOS; Annonymous 2003).

Question WWF: "The goshawk can barely be used for anything that justifies hunting.

Additionally the goshawk is a protected raptor. Why does the NHA wish to hunt this species?"

Answer NHO: "It is nothing new under the sun that we wish to hunt goshawk. Our opinion is that goshawk stocks will stand up to hunting pressure and species that tolerate hunting ought to be harvested."

Question WWF: "But goshawks can't even be food?"

Answer NHO: "No, but the goshawk is a competitor for us. It takes a huge number of black grouse and hazel grouse. Goshawk is an attractive game species for the hunters too."

Comments GSNOS: "The goshawk became protected in 1971. There is nothing that indicates an increasing trend in the population. It is also a bit remarkable to say that the species is a competitor to the hunter. It is more correct to say that the hunters are competitors of the goshawks." And "The goshawks prefer old-growth forests and find conditions bad in present clear-cut dominated forest landscapes."

1998). Therefore, debates about the status of the goshawks will continue, and further research seems imperative.

\subsubsection{Hunting argumentation}

During the last decades, several attempts to re-establish hunting of goshawks, both as an official statement from hunting associations and statements from individual hunters have been attempted (Table 2). The Norwegian Hunting Association (NHA) has not yet stated formally that the war against raptors has ended, and this association occasionally still recommends goshawk hunting. Their arguments can be summarized as follows: 1) The goshawks compete with hunters for small game species as well as being our most common raptor, and history has told us that the species can tolerate significant hunting pressure. 2) Hunting in autumn and wintertime should not cause any problem for the species and is an old traditional practice that ought to be maintained in the future. Conversely, arguments against hunting are more often based on goshawks being a vulnerable species due to forestry practices and the danger of misidentifying and inadvertently killing other raptors that are even rarer. Goshawks are popular for collectors and captivity, and if hunting is legalized again, such activity will probably become more common. One could also argue a pedagogical perspective, that hunting will generally reduce respect for raptors' ecological role in nature.

Underlying all these arguments is the assumption that scattered hunting of goshawks will have limited effects on the abundance of small game species. As people become more urbanized, they also argue that to hunt species that are not considered suitable as food is reprehensible. The Norwegian name of goshawk is "hønsehauk" indicating that they mainly prey on Galliformes. What if the species name is changed to "duehauk" (pigeon hawk), similar to the name in Sweden? This name will provide information that pigeons, as correctly, are far more important prey items. Yet a suggestion to change the name would probably cause massive protests among the public, confirming the political and symbolical role of the species.

\subsubsection{Attention in the media}

The most common media focus on goshawks today deals with rare observations and situations in daily life. The 1995-2003 archives of the main newspaper Aftenposten feature several articles reporting that goshawks are threatened by logging of nest sites, and people are sentenced when they have killed goshawks. An important legal question surrounds whether killing a goshawk constitutes self-defence because poultry are domestic species. Recently, in 1997, there was one shooting of a goshawk that was taken to the highest court in Norway (Aftenposten 29. august 1997). The lowest level court ruled in favour of the self-defence argument. The appellate court rejected this decision but was in turn overruled by Supreme Court. The official bureaucratic stance pertaining to the goshawk has changed completely. Today it is very difficult to get a permit to kill 
goshawks that do damage to farm poultry, because the goshawk is listed as a red list species (Near threatened).

There has been special focus on Capercaillie Tetrao urogallus lek areas and goshawk nest areas in forest management in Norway since the early 1990s. The forestry authorities have made specific recommendations for logging activities in such areas, including protection or strong harvest restrictions. To some extent these recommendations have been controversial, and still cause conflicts between forest owners and nature protection agencies. The main source for the conflict is caused by uncertainty as to what effects clear cutting has on population size and density of these species at landscape scale (Gundersen et al. 2004). However, the role of goshawk as flagship species symbolizing old-growth forest is obviously an important factor for today's forest management recommendations, and also an important consideration for the forest industry in order to establish goodwill and environmentally friendly reputation among the public.

The symbolic value of goshawks originated from the old myths of wilderness. The possibility for the public to experience rare and fascinating species has gained more and more importance in the argument for goshawk preservation and conservation. In forest landscapes surrounding Oslo, Norway's capital city, there are 14 protected forest areas. The goshawk is presented as one of the most fascinating species you can see in these areas (Anonymous 2004). You can also find such statements in descriptions of recreational forests today "..if you take a walk away from forest roads you can find old-growth natural forests with goshawks and other rare species". This statement links goshawks to old-growth forests, thereby implying that one will not find the species in managed forests. A larger part of the continuous boreal forest in Norway is situated in the Finnskogen area, and here is an excerpt from an advertisement for a book: "In shining spring mornings you can hear the blackcock [Tetrao tetrix] mating ritual on mires and ice covered tarns and deep in the forest goshawk and golden eagle are nesting" (Anonymous 1997). The symbolic value of goshawks is highly acknowledged in commercials for beautiful tourist wilderness: "Varaldsøy - the beauty spot in Hardanger...Here you can find goshawks, sea eagles [Haliaeetus albicilla] and falcons...." One can argued that the circle is completed; the symbolic values like those present in the early fairy tales have regained attention today, and still influence the public attitude and legislation for the goshawks and their habitats.

\section{DISCUSSION}

Literature from earlier times, describes the goshawk as a predator that symbolized heroism and bravery. This can be perceived as a positive attitude among people towards the species (although the generality of this attitude for this period is still an open question). In the 1800 s, hunters, farmers and key ecologists all viewed the goshawk as a vermin species. To put a bounty on goshawks was initially never a question of ethics, but about the demographic effects of the treatment and to some extent about confusion with other useful raptor species (e.g. mouse predators). The separation between vermin and utility species was not much questioned among leading ecologists in the time before 1910 .

In the 1800s, the objective of exterminating goshawks and other competitors for food was considered "common sense". Because goshawks prey upon smallgame species, the rationale at the time was simply that fewer goshawks would mean more game. The words used by scientists in their papers, cowardly, greedy, harmful, dangerous enemy, ravages, ruin the farms poultry, huge damage (Rasch 1845, Collett 1905), are evidence that their recommendations for management were far from objective, but rather influenced by their perceptions and attitudes. Yet their statements need to be viewed in the context of the time they were written. Norway's identity as a nation was being built at that time, focusing on the opportunities to produce more food and timber despite limited resources available to the population.

Both before 1850 and in the years that followed, there were many examples of aesthetic descriptions of goshawks that portray them as a shy, mysterious species that lived deep in the forest (e.g. Rasch 1845, Collett 1898, 1905, 1921). But positive aesthetic descriptions of the species did not play a meaningful role in the discussion among scientists before 1920 . After 1920, however, scientists began including aesthetic descriptions in their scientific papers about goshawks, to engage the people against what they called: "the meaningless extermination of raptors" (e.g. Broch 1920, 1930, Brinkmann 1926, Løvenskiold 1947, Barth 1957, Huse 1958). Although published as a popular-science piece, an article written by the biologist Huse (1958) describing the "balance in nature", stated that "all human intervention is bad for the balance in nature." Both phrases indicate an aesthetic view of nature, as illustrated by another of his sentences: "Raptors flying high up in the sky are symbolic of the freedom and the spirit of Norwegian nature." (Huse 1958). The Clementsian ecological paradigm, which treated communities of species as super-organisms (Clements 1916), was also quite popular at that time. Clements' concept that ecosystems progress towards a state of equilibrium was integrated into the national consciousness as the "balance in nature". The Norwegian novelist Mikkjel Fønhus frequently wrote about how other species experience both their natural environment and humans. His book "Det skriker fra Kverrvilljuvet" (1920) describes the life of a goshawk family living out in the wilderness. Given how popular 
his books were at the time, his stories are probably still important for formation of public attitudes towards the goshawk.

In the 1960s and 1970s, arguments for bounty on goshawks became weaker and more seldom heard. Many voices were raised to protect the goshawks. Willgohs (1968) wrote "in the last few years you can find a noticeable change in the opinion towards raptors of the man in the street". There was a general demand that this shifting opinion should be reflected in the law (Barth 1982). The 1960s also brought general concern about declining trends for goshawks and other raptor species due to habitat destruction, harmful chemicals (DDT) and other pollutants (Newton 1979). As a consequence, all raptors and owls became protected by law in 1971. Finally, the new hunting act of 1981 ended the distinction between vermin and utility animals, resulting in the protection of all Norwegian vertebrate species if not otherwise stated. During the period with bounty on goshawks, from 1846 to 1971 altogether 331,349 bounties of goshawk were reported to national authorities. The environmental movement in the 1960s and 1970s was a reaction against the utilitarian view of nature, as a resource to satisfy our demands. Selås, I. (1998) concluded in his historical review that attitudes towards goshawks have totally changed today compared with the extermination period in the $1800 \mathrm{~s}$.

Research activity on the species increased in the 1970 s, initially because of negative effects that goshawk protections was expected to have on populations of small-game species. This work identified negative population trend for the goshawks, and subsequent studies were aimed at determining the cause. The resulting scientific papers excluded ethical and aesthetic descriptions of the goshawk. However, the goshawk remains a charismatic species that represents a considerable amount of symbolic value in the media (Marcström et al. 1990), reinforcing a popular will to manage forests to ensure its conservation. The presence of goshawks in a forest landscape is still used as a symbol of a healthy forest ecosystem, and peoples' perception of a mystical old-growth dependent forest species is still highlighted in the media.

Modern conservation biology can be considered an applied branch of ecology, constantly trying to define the balance between exploitation and protection of natural resources. By strongly addressing the ethical axis, especially the sustainability concept (Lubchenco 1998), the number of conflict areas towards industrial economies are constantly rising. The core of such conflicts is often characterized by diverging perceptions regarding sustainable utilization of living resources, such as forests, predators and traditional game species. Parallel to the fact that human impact on natural habitats, and hence biodiversity, is increasingly negative, it seems problematic to attach such conservation arguments sufficient importance for the society compared to e.g. short-time economic yield among landowners, or hunters desire to eliminate other competitors for game resources. Such uncritical biomanipulation attitudes among people are probably rooted in many world religions as well as western philosophies and scientific work (Pullin 2002), claiming that humans are the superior organism owing both rights and insights to exploit and control natural resources for their own benefit. People's attitudes towards predators, as illuminated in this article, offer an excellent example on this matter. Control programmes for medium-sized predators, such as goshawk, red fox and pine marten Martes martes, are exclusively motivated by an industrial-like philosophy aiming to optimize the harvest of traditional game species, and fail to take into account the multiple ecological role such species play in the ecosystem. In our opinion, public attitudes have failed to take into consideration the development of multiple science disciplines during one century.

As an old-growth adapted species requiring large territories, goshawks represent a potential umbrella indicator species, serving as a surrogate to determine the size of area or type of habitat in cases in which the conservation goal is to protect a habitat or a community of species (Simberloff 1998), and flagship species, attracting the public attention for promoting conservation goals (Caro \& O'Doherty 1999). The flagship species concept involves people's aesthetic evaluations, integrating ecology and aesthetics. The American conservationists and wildlife scholar Aldo Leopold (1887-1948) borrowed the term numenon from philosophy to describe an aesthetic aspect of natural areas (Leopold 1949), indicating that presence of top predators (and raptors) is the hallmark of respective ecological communities. Callicott (1983) called "aesthetic indicator species" numena: if these species are missing, the landscape lacks perfect health. Accordingly, goshawks' role as a kind of indicator species involves more than a visual experience of the goshawk itself, and it is also more than pure ecological evidence. Goshawk presence provides (at least) a perception of a healthy landscape, and a sense that everything is in order.

No other raptors in woodlands have generated more controversy than the goshawk: as a symbol of bravery and heroism, as a predator on poultry and game species, and as a vulnerable species dependent of old-growth forests, and as a beautiful and mysterious creature living deep in the forests. In the absence of wolf, brown bear and lynx in many Norwegian boreal forest landscapes, goshawk may be used as an aesthetic indicator species. Most people value the goshawk not only for ecological reasons, but also for their ethical and aesthetical values and roles in forest landscapes (Myrvang 2006). Some contend that one does not need to see or hear goshawks; it is often enough merely to 
know that they are present in an area. If this is true, pure ecological and demographic information are not enough to manage goshawk populations, but goshawk management has to take into consideration people's attitudes and perceptions of the species.

Acknowledgements. We want to thank Inge Selås and one anonymous referee for very valuable comments of the first submission of the manuscript. Thanks also to Erik Stange, Norwegian Institute of Nature Research, for valuable comments and for language editing the manuscript.

Sammendrag. Argumentasjon for jakt på hønsehauk (Accipiter gentilis) i Norge gjennom tidene beskrevet av jegere, viltforskere og naturvernere. Hønsehauken har influert folks liv siden tidlig sivilisasjon. I de første nedtegnede skrevne kildene om arten, i Vikingtiden fra 8001050 e.kr., symboliserer hønsehauken heltemot og dyktighet. Det var mye mystikk og overtro knyttet til hønsehauken og bevis på dette kan finnes fra gamle runer og senere i eventyr og ordtak. Artikkelen beskriver den vitenskapelige og etiske argumentasjonen for å gi skuddpremie på arten i perioden 1845 til 1971. I starten på perioden var det bare et fåtall innflytelsesrike personer som påvirket myndighetene til å gi skuddpremie på den og utarbeide lovverk for dette i 1845 , $1863 \mathrm{og} 1899$. Fra $1910 \mathrm{og}$ fremover ble argumentasjonen for eller imot skuddpremie mer mangfoldig og til slutt resulterte det, til at arten ble fredet i 1971. Med viltloven i 1981 ble det fra offisielt politisk hold slutt på å skille mellom skadeog nyttedyr i naturen, og hønsehauken har vært listet på de nasjonale rødlista siden 1984. Hønsehauk er et godt eksempel på en art som har samvirket med mennesket i lang tid og som inkluderer sterke følelser fra både de som ser på den som en konkurrent og fra de som ser på den som en naturlig del av økosystemet. Selv om forvaltningen av hønsehauk i dag skal være kunnskapsbasert, er vår påstand at også andre verdier som symbolverdi og estetisk verdi påvirker forvaltningen av arten.

\section{REFERENCES}

Anonymous 1845a. Indstilling fra Nærings-Commiteen No.1 til Lov om Utryddelse af Rovdyr og Fredning af andet Vildt. 1845. No. 278. (In Norwegian).

Anonymous 1845b. Lov af 4de August 1845 om Utryd-delse af Rovdyr og Fredning av annet Vildt. (In Norwegian).

Anonymous 1863a. Lov af 22de Juni 1863 om Utryd-delse af Rovdyr og Fredning av annet Vildt. (In Norwegian).

Anonymous 1863b. Læsebog for Folkeskolen og Folkehjemmet. J.W. Cappelens Forlag, Kristiania. (In Norwegian).

Anonymous 1894. Høgelok. Norsk Jæger- og Fiskerforenings Tidsskrift 23: 84-89. (In Norwegian).

Anonymous 1898. Den Parlamentariske Landbrugskommission. 1898. Angaaende Forslg til Jagtlov. Stortingsforhandlingene, 5. del. (In Norwegian).

Anonymous 1899. Lov angaaende jagt og fangst av 20de mai 1899. (In Norwegian).
Anonymous 1903. Mindre meddelelser. Norsk Jæger- og Fiskerforenings Tidsskrift 32: 61. (In Norwegian).

Anonymous 1906. Hønsehøg og spurvehøg. Jagt og fangst. Norsk Jæger- og Fiskerforenings Tidsskrift 35: 102-108. (In Norwegian).

Anonymous 1910. Utrydning - eller indskrænkning av rovdyr? Tidsskrift for skogbruk 11: 277-278. (In Norwegian).

Anonymous 1925. Rovfugl og kraake. Norsk Jæger- og Fiskerforenings Tidsskrift 54: 210. (In Norwegian).

Anonymous 1932. Lov angaaende jagt og fangst av 3. mars 1932. (In Norwegian).

Anonymous 1951. Lov av 14. desember 1951 om viltstellet, jakt og fangst. (In Norwegian).

Anonymous 1969. Vi treng ei systematisk utrydding av rovviltet. Fædrelandsvennen 19/8-1969. (In Norwegian).

Anonymous 1972. Meningsløst at hønsehauken fredes. Dagbladet 7/4-1972. (In Norwegian).

Anonymous 1981. Lov av 29. mai 1981 om viltet. (In Norwegian).

Anonymous 1984. Truete planter og dyr i Norge. Statens Naturvernråd. (In Norwegian).

Anonymous 1988. Truede virveldyr i Norge. Rapport 2. Direktoratet for naturforvaltning, Trondheim. (In Norwegian).

Anonymous 1992. Truete arter i Norge. Rapport 6. Direktoratet for naturforvaltning, Trondheim. (In Norwegian).

Anonymous 1997. http://www.photographica.no/boker/ baksyv/finnskog.htm (In Norwegian, Sept. 2011).

Anonymous 1999. Nasjonal rødliste for truete arter i Norge 1998. Rapport 3. Direktoratet for natur-forvaltning, Trondheim. (In Norwegian).

Anonymous 2001. http://www.jeger.no/text.cfm/ 490+1+8+96 (In Norwegian, Sept. 2011).

Anonymous 2003. http://www.wwf.no/core/200310/ 08a.asp (In Norwegian, Sept. 2011).

Anonymous 2004. http://erfaring.com/om/search.php (In Norwegian, Sept. 2011).

Anonymous 2005. http://www.nrk.no/programmer/tv/ ut i naturen/4956507.html (In Norwegian, Sept. 2011).

Asbjørnsen, P.C. \& P. Moe. 1845. Norske folkeventyr. Ny samling, Kristiania. (In Norwegian).

Barth, E.K. 1957. Rovviltet i naturens husholdning. Naturvern i Norge. Årsskrift 1: 5-12. (In Norwegian).

Barth, E.K. 1982. Jaktlov og viltforvaltning i Norge. Et tilbakeblikk. Vår Fuglefauna 4: 244-251. (In Norwegian)

Bijlsma, R.G. 1991. Trends in European goshawks (Accipiter gentilis): An overview. Bird Census News 4: 3-47.

Brinkmann, A. 1926. Coccidiosen hos lirypen. Bergens Museums Aarbok: 1-73. (In Norwegian).

Broch, H. 1912. Rovdyrfangsten og likevegten i naturen set fra zoologisk standpunkt. Norsk Jæger- og Fiskerforenings Tidsskrift 41: 321-332. (In Norwegian).

Broch, H. 1920. Naturfredningen i Danmark og Sverige og hvad det er gjort hos oss. Norsk Ornithologisk Tidsskrift 5: 25-28. (In Norwegian).

Broch, H. 1928a. Rovfuglsaken og NJ \& FF. Norsk Jæger- og Fiskerforenings Tidsskrift 57: 34-35. (In Norwegian). 
Broch, H. 1928b. Internasjonal fuglebeskyttelse. Norsk Ornithologisk Tidsskrift 7: 68-75. (In Norwegian).

Broch, H. 1930. Vern naturen! Norge. Tidsskrift om vårt land: 104-107. (In Norwegian).

Broch, H. 1954. Zoologiens historie til annen verdenskrig. Oslo. (In Norwegian).

Callicott, J.B. 1983. Leopold's land aesthetic. Journal of Soil and Water Conservation 38: 329-332.

Caro, T.M. \& O`Doherty, G. 1999. On the Use of Surrogate Species in Conservation Biology. Conservation Biology 13: 805-814.

Clements, F.E. 1916. Plant succession: An analysis of the development of vegetation. Carnegie Institute of Washington.

Collett, R. 1898. Bemærkninger vedrørende Norges Pattedyrfauna, 3die Række (1882-1897). Nyt Magazin for Naturvidenskaberne 36: 276-297. (In Norwegian).

Collett, R. 1905. Norges præmieværdige Rovfugle. En veiledning. En Vejledning udarbeidet efter Anmodning af Landbrugsdepartementet, Kristiania. (In Norwegian).

Collett, R. 1921. Norges Fugle. Aschehoug, Kristiania. (In Norwegian).

Crocker-Bedford, D.C. 1990. Goshawk reproduction and forest management. Wildlife Society Bulletin 18: 262269.

Crocker-Bedford, D.C. 1995. Northern Goshawks reproduction relative to selection harvest in Arizona. Journal of Raptor Research 29: 42-43.

Crocker-Bedford, D.C. 1998. The value of demographic and habitat studies in determining the status of Northern Goshawks (Accipiter gentilis atricapillus) with special reference to Crocker-Bedford (1990) and Kennedy (1997). Journal of Raptor Research 32: 329-336.

Dahl, K. 1927. Rovvildtet i vor jagthusholdning. Norsk Jæger- og Fiskerforenings Tidsskrift 56: 369-377. (In Norwegian).

Eger, W. 1924. Rovdyrsaken. Har Norsk Jæger- og Fiskerforenings arbeide for rovdyrsaken virkelig været til skade for vor vildtbestand? Norsk Jæger- og Fiskerforenings Tidsskrift 53: 26-30. (In Norwegian).

Feragen, A. 1903. Kort veiledning i fangst av mindre rovdyr, rovfugl og kraaker. Norsk Jæger- og Fiskerforening, Kristiania. (In Norwegian).

Forsman, D. \& Ehrnstén, B. 1985. Is the goshawk Accipiter gentilis declining? Lintumies 20: 83-88.

Gjorde, A. 1932. Rovdyrene. Norsk Jæger- og Fiskerforenings Tidsskrift 61: 178-183. (In Norwegian).

Gran, H.H. 1911. Botanikken og zoologien. I: Det kongelige Fredriks Universitet 1811-1911. Festskrift, bind 2: 539575. (In Norwegian).

Grønlien, H., Høitomt, G. \& Opheim, J. 1993. Registreringer av skoglige forhold ved 10 hekkelokaliteter for hønsehauk. En vurdering av biotopkrav og bestandsutvikling. Fugler i Oppland 14: 1-103. (In Norwegian).

Grønlien, H. 2004. Hønsehauken i Norge - Bestandens status og utvikling siste 150 år. NOF Rapportserie 5: 1-41. (In Norwegian)
Gundersen, V. \& Rolstad, J. 1998. Truete arter i skog en gjennomgang av rødlistearter i forhold til norsk skogbruk. Norsk Institutt for skogforskning, Ås.(In Norwegian).

Gundersen, V., Rolstad, J. \& Wegge, P. 2004. Hønsehauk og skogbruk - en gjennomgang av bestandsutvikling, økologi og trusler. Agricultural University of Norway, Ås. (In Norwegian, with English summary).

Hafstad, I. 2002. Hønsehauk vs. skogbruket - en kilde til stadig konflikt. Vår Fuglefauna 25: 82-86. (In Norwegian)

Hafstad, I., Steinsvåg, M.J., Nordvik, T.O. \& Sandvik, J. 2003. Hvordan påvirker forskjellige fysiske inngrep hekkesuksessen til hønsehauk? Vår Fuglefauna 26: 16-17. (In Norwegian).

Hagen, Y. 1952. Rovfuglene og viltpleien. Universitetsforlaget, Oslo. (In Norwegian).

Hagen, Y. 1964. Rovviltet. Østlandske naturvern-forenings småskrift 6. Oslo. (In Norwegian).

Hals, A. 1998. Hønsehauken - granskogens rovfugl. Skogeiereren 8: 22-23. (In Norwegian).

Hals, A. 1999a. Norges "Spotted Hawk". Skogeieren 12: 2. (In Norwegian).

Hals, A. 1999b. Hønsehauken - spesialisten som sliter. Skogeieren 8: 22-24. (In Norwegian).

Haugan, R. \& Søgnen, S.M. 1999. Hønsehauken - skogbrukets ansvar! Skogeieren 12: 26-27. (In Norwegian).

Hayward, G.D. \& Escano, R.E. 1989. Goshawk nest-site characteristics in western Montana and northern Idaho. Condor 91: 476--479.

Helland, A. 1914. Rovdyrene i Norge. Tidsskrift for Skogbrug 2: 90-104. (In Norwegian)

Henttonen, H. 1989. Does an increase in the rodent and predator densities, resulting from modern forestry, contribute to the long-term decline in Finnish tetraonids? Soumen Riista 35: 83-90. (In Finnish, with English summary).

Hesthagen, T. 1975. Svingninger i harebestanden og mulige faktorer som forårsaker disse. University of Tromsø, Tromsø. (In Norwegian).

Hjeljord, O. 1980. Viltbiologi. Landbruksforlaget, Oslo. (In Norwegian).

Hovden, O. 1874. Letter. Setelarkivet: http://www.dok. hf.uio.no/perl/search/search.cgi?tabid=436\&appid=8 (In Norwegian, Sept. 2011).

Huse, S. 1958. Skal de få lov til å leve? Betraktninger over "nyttige" og "skadelige" dyr i vår fuglefauna. Naturvern i Norge. Årsskrift 1958: 4-7. (In Norwegian).

Jenssen, E. 1931. Vårt småvilt og rovviltet. Norsk Jæger- og Fiskerforenings Tidsskrift 60: 169-173. (In Norwegian)

Johnsen, S. 1929. Rovdyr- og rovfuglstatistikken i Norge. Bergens Museums Årbok, Naturvidenskapelig rekke 2: 1-118. (In Norwegian).

Kennedy, P. 1997. The Northern Goshawk (Accipiter gentilis atricapillus): Is there evidence of a population decline? Journal of Raptor Research 31: 95-106.

Kjær, N. 1912. Nye epistler. Kristiania. (In Norwegian).

Knoff, C. 1996. Er hønsehauken truet i Hedmark? Kornkråka 
26: 21-24. (In Norwegian).

Knoff, C. 1999a. Blir bestandsskogbruket hønsehaukens bane? Vår Fuglefauna 22: 81-86.

Knoff, C. 1999b. Blir bestandsskogbruket hønsehaukens bane? Rapport fra NOF, Hedmark. (In Norwegian).

Kålås, J.A., Viken, Å., Henriksen, S. \& Skjelseth, S. (eds.). 2010. The 2010 Norwegian Red List for Species. Norwegian Biodiversity Information Centre, Trondheim, Norway.

Leopold, A. 1949. A Sand County Almanac with essays on conservation from Round River. Ballentine Books, New York.

Lind, G. 1970. Duvhöken och det moderna skogsbruket. Meddelanden från Dalarnas Ornitologiska Förening 3: 6-7. (In Swedish).

Lindén, H. \& Rajala, P. 1981. Fluctuations and long term trends in the relative densities of tetraonid populations in Finland 1964-1977. Finnish Game Research 39: 13-34.

Lindström, E.R., Andrén, H., Angelstam, P., Cederlund, G., Hörnfeldt, B., Jäderberg, L., Lemnell, P.A., Martinsson, B., Sköld, K. \& Swenson, J.E. 1994. Disease reveals the predator: Sarcoptic mange, red fox predation, and prey populations. Ecology 75: 1042-1049.

Lubchenco, J. 1998. Entering the century of the environment: a new social contract for science. Science 279: 491-497.

Løvenskiold, H. L. 1925. Svingninger i harebestanden. Norsk Jæger- og Fiskerforenings Tidsskrift 54: 154-156. (In Norwegian).

Løvenskiold, H. L. 1947. Håndbok over Norges fugler. Gyldendal, Oslo. (In Norwegian).

Marcström, V. 1979. A review of the tetraonid situation in Sweden. Proceedings of the International Grouse Symposium 1: 13-16.

Marckström, V., Kenward R.E. \& Engren, E. 1988. The impact of predation on boreal tetraonids during vole cycles: An experimental study. Journal of Animal Ecology 57: 859-872.

Marcström, V., Kenward, R.E. \& Karlbom, M. 1990. Duvhöken och dess plats i naturen. Vidar Marcström förlag, Uppsala. (In Swedish).

Munthe-Kaas Lund, H. 1950. Et bidrag til kjennskapen om hønsehaukens næring i Norge.

Skogdirektørens årsmelding 1943-1947: 1-27. (In Norwegian)

Myrvang, G. 2005. Turfolks holdninger til forvaltning av storfugl og hønsehauk. Mastergrad Universitetet for miljø- og biovitenskap, Institutt for naturforvaltning, Ås.

Newton, I. 1979. Population ecology of raptors. T \& A D Poyser, Berkhamsted, UK.

Niemi, G.J. \& Hanowski, J.M. 1997a. Concluding remarks on raptor responses to forest management: A holarctic perspective. Journal of Raptor Research 31: 191-196.

Niemi, G.J. \& Hanowski, J.M. 1997b. Raptor responses to forest management: A holarctic perspective. Journal of Raptor Research 31: 93-94.

Nilsson, S.G. 1981. Det svenske rovfågelbeståndets storlek. Vår Fågelvärld 40: 249-262. (In Swedish).

Norderhaug, M. 1978. Status og vern av hønsehauken i
Europa. Vår Fuglefauna 1: 98-99.

Økland, F. 1946. Skogens pattedyr og fugler. Grøndahl \& Søn, Oslo. (In Norwegian).

Olsen, M. 1941. Norske innskrifter med de yngre runer, andre bind. Norsk Historisk Kjeldeskrift-institutt, Oslo.

Pedersen, Å.Ø. 2000. Hønsehauk i fare. Norsk Natur 15: 22-23. (In Norwegian).

Pullin, A.S. 2002. Conservation biology. Cambridge University Press, New York. 345 pp.

Rasch, H.H. 1838. Fortegnelse og Bemerkninger over de i Norge forekommende Fugle. Nyt Magazin for Naturvidenskaberne: 357-389. (In Norwegian).

Rasch, H.H. 1845. Jagten i Norge. En Skildning af den nuværende Tilstand, samt Motiver og Forslag til Lovbestemmelser sigtende til at fremme dens hensigtsmæssige Udøvelse. Kristiania. (In Norwegian).

Rasch, H.H. 1860. Forslag til Forandringer i Loven av 4.de August 1845 om Utryddelse af Rovdyr og Fredning af andet Vildt, ledsagede af Motiver samt udkast til en ny Lov. Stortingsforhandlingerne 1862-63: 1-12. (In Norwegian).

Rasch, H.H. 1862. Bidrag til Norges Rovdyr- og Rovfuglestatistikk. Christiania. (In Norwegian).

Rasch, H.H. 1868. Bidrag til Norges Rovdyr- og Rovfuglestatistikk for femaaret 1861-1865. Christiania. (In Norwegian).

Reynolds, R.T., Graham, R.T., Reiser, M.H., Basset, R.L., Kennedy, P.L., Boyce, D.A., Goodwin, G., Smith, R., \& Fisher, E.L. 1992. Management recommendations for the Northern Goshawk in the southwestern United States. USDA Forest Service, Gen. Tech. Rep. RMRSGTR-217, Fort Collins, USA.

Rygh, O. 1898. Norske Gaardnavne. Bind 1-18. (http://www. dokpro.uio.no/rygh_ng/rygh_felt.html) (In Norwegian, Sept. 2011).

Sandvik, J. 1996. Hønsehaukens status i Sør-Trøndelag. NINA-Temahefte 5: 16-19. (In Norwegian).

Schaaning, H.T.L. 1927. Kjendte fuglearter fra Norges stenog jernalder. Stavanger. (In Norwegian).

Selås, I. 1998. Rovfuglsynet før og nå - med særlig vekt på hønsehauken. Vår Fuglefauna 21: 53-59. (In Norwegian)

Selås, V. 1998. Hønsehaukbestanden i tilbakegang - også i Aust-Agder. Vår Fuglefauna 21: 149-154.

Selås, V., Smedshaug, C.A., Lund, S.E. \& Sonerud, G.A. 1995. Revskabbens betydning for småviltet i Norge. - Brosjyre, Institutt for Naturforvaltning, Norges Landbrukshøyskole, 2 pp.

Shuster, W.C. 1980. Northern goshawk nest site requirements in the Colorado Rockies. Western Birds 11: 89-96.

Simberloff, D. 1998. Flagships, umbrellas, and keystones: Is single-species management passé in the landscape era? Biological Conservation 83: 247-257

Skåret, B. 1997. Hvordan vi ble lurt. Om Bernkonvensjonen som rovdyrpolitisk verktø. Internettside:http://www. rovdyr.org/rovdyr/arkiv/lurt.html (In Norwegian, Sept. 2011).

Smedshaug, C.A. 2001. Was high grouse bag in early 20th 
century Norway due to a program for extermination of small game predators? Ecography 24: 579-587.

Sollien, A. 1979. Bestandsutviklingen hos hønsehauk Accipiter gentilis, i Norge de siste 100 år. Vår Fuglefauna 2: 95-106. (In Norwegian).

Statistisk Sentralbyrå, 1978. Jaktstatistikk 1846-1977. Norges Offisielle Statistikk 955: 1-195. (In Norwegian)

Storaker, H. 1928. Naturrigerne i den norske folketro. Oslo. (In Norwegian).

Waage, L.G. \& Jonassen, T. 2004. Fuglene i norsk tradisjon. Truer. Varsel. Jakt. Fangst. http://www.floraskulen.no/ fagsider/natur-miljo/fugl/generell_1.htm (In Norwegian, Sept 2011).

Tømmeraas, P.J. 1993. Hønsehauken i Leksvik - et offer for det moderne skogbruket. - Fauna 46: 180-195.

Wegge, P. \& Grasaas, T. 1977. Bestandsstudier av storfugl på Sørlandet. Viltrapport 5: 22-39. (In Norwegian).

Wegge, P. 1979. Status of capercaillie and black grouse in Norway. Proceedings of the International Grouse Symposium 1: 17-26.

Wille, K. 1786. Setelarkiv: http://www.dok.hf.uio.no/perl/ search/search.cgi?tabid=436\&appid=8 (In Norwegian, Sept. 2011).

Widén, P. 1989. The hunting habitats of goshawk Accipiter gentilis in boreal forests of central Sweden. Ibis 131: 205-231.

Widén, P. 1997. How, and why, is the Goshawk (Accipiter gentilis) affected by modern forest management in Fennoscandia? Journal of Raptor Research 31: 107-113.

Wille, H. 1786. Letter. Setelarkivet: http://www.dok.hf.uio. no/perl/search/search.cgi?tabid=436\&appid=8 (In Norwegian, Sept. 2011).

Willgohs, J.F. 1968. Bedre vern av våre rovfugler. Sterna 8: 1-12. (In Norwegian).

Received 6 September 2011, accepted 27 December 2011 